\title{
The transforming mutation EI7KJAKTI is not a major event in B-cell-derived lymphoid leukaemias
}

\author{
IS Mahmoud', MA Sughayer², HA Mohammad', AA Eshtayeh', AS Awidi', MS EL-Khateeb' and SI Ismail*,I \\ 'Department of Biochemistry, Faculty of Medicine, University of Jordan, Amman I 1942, Jordan; '² Department of Pathology, King Hussein Cancer Center, \\ Amman 1/941, Jordan
}

Despite the major role of the AKT/PKB family of proteins in the regulation of many growth and survival mechanisms in the cell, and the increasing evidence suggesting that AKT disruption could play a key role in many human malignancies, no major mutations of AKT genes had been reported, until very recently when Carpten et al reported a novel transforming mutation (EI7K) in the pleckstrin homology domain of the AKTI gene in solid tumours. Several laboratories are now screening for this mutation in different malignancies, and, recently, the mutation was described by Malanga et al in 1.9\% of lung cancer patients. Considering the importance of the PI3K/AKT pathway in mediating survival and antiapoptotic signals in the B-cell types of chronic lymphocytic leukaemia (CLL) and acute lymphoblastic leukaemia (ALL), we sequenced the AKTI exon 3 for the above mentioned mutation in 87 specimens, representing $45 \mathrm{CLLs}, 38 \mathrm{ALLs}$ and 4 prolymphocytic leukaemia (PLL) cases, which are all of B-cell origin. Our results show that the mutation EI7KIAKTI was not detected in the pleckstrin homology domain of AKTI of the investigated cases. We conclude that this mutation is not a major event in B-cell-derived lymphoid leukaemias.

British Journal of Cancer (2008) 99,488-490. doi:10.1038/sj.bjc.66045I2 www.bjcancer.com

Published online 29 July 2008

(c) 2008 Cancer Research UK

Keywords: AKTI; lymphoid leukaemia; mutation

The v-akt murine thymoma viral oncogene homologue (AKT) is a well-established survival factor exerting variable activities, including cell survival, growth, proliferation, metabolism and glucose uptake (Nicholson and Anderson, 2002; Elstrom et al, 2004; Hanada et al, 2004; Manning and Cantley, 2007). Mounting evidence is showing the importance of AKT proteins in human malignancies (Testa and Bellacosa, 2001; Altomare and Testa, 2005; Bellacosa et al, 2005; Plas and Thompson, 2005). One of the first such indications was provided by the isolation of a novel transforming retrovirus 'AKT-8' from an AKR mouse T-cell lymphoma (Staal et al, 1977). This transforming retrovirus was subsequently shown to contain an intact viral oncogenic sequence called v-akt (Staal and Hartley, 1988). Since then, many studies have described perturbations of the AKT signalling pathway in multiple human cancers, which have been reviewed elsewhere (Altomare and Testa, 2005). However, mutational analysis attempted to find any genetic abnormalities of AKT kinase domains in common human malignancies revealed no major genomic alterations in the three AKT isoforms (Soung et al, 2006), although some reports described some minor alterations in some of the isoforms associated with specific malignancies (Robertson et al, 2005).

In July 2007, Carpten et al published a very interesting study on the AKT1 gene in Nature, where they detected a novel transforming mutation involving a glutamic acid (E) to lysine (K) substitution at amino acid 17 (E17K) in the pleckstrin homology domain of the AKT1 gene. This $\mathrm{E} 17 \mathrm{~K}$

*Correspondence: Dr SI Ismail, Department of Biochemistry, Faculty of Medicine, University of Jordan, Amman I 1942, Jordan;

E-mail: sismail@ju.edu.jo

Received 30 April 2008; revised 16 June 2008; accepted 17 June 2008; published online 29 July 2008 point mutation was identified in $8 \%$ of breast cancers, $6 \%$ of colorectal cancers and $2 \%$ of ovarian cancers (Carpten et al, 2007). Screening studies to find this novel mutation in other cancers were carried out by different investigators in the past few months. Although Tibes et al (2008) and Schüller et al (2008) did not find the mutation in acute myeloid leukaemia, and glioblastomas and medulloblastomas, respectively, the mutation was detected in $1.9 \%$ of lung cancers; where it represented $5.5 \%$ of the squamous cell carcinoma histotype (Malanga et al, 2008).

Chronic lymphocytic leukaemia (CLL) is the most common type of leukaemia in older adults in the West (Inamdar and Bueso-Ramos, 2007). Chromosome defects are the most common genetic abnormalities seen in CLL, and the last decades have seen much progress in delineating the role of these genetic aberrations in the pathogenesis of CLL (Cotter and Auer, 2007). However, the genetics of CLL is still not fully understood. The PI3K/AKT pathway has been shown to play a central role in promoting cell survival and growth of B-cell CLL (Barragán et al, 2002, 2006; Cuní et al, 2004; Petlickovski et al, 2005; Longo et al, 2007). Also, in a recent study, Longo et al (2008) described the critical role of AKT in mediating the antiapoptotic signals along with Mcl-1 downstream of the B-cell receptor in CLL. Similarly, AKT has been described to mediate survival of precursor B-acute lymphoblastic leukaemia (pre-BALL) cells through activation of RAFTK, which plays an antiapoptotic role (Sarkar et al, 2002). Also, Wang et al (2004) have showed the pivotal role of Akt in mediating stromal cell regulation of ALL cell apoptosis.

Considering the central role of AKT in CLL and ALL, we performed a screening study in an attempt to detect the mutation E17K/AKT1 in these types of haematological malignancies. 
Table I Characteristics of patient samples

\begin{tabular}{lccc}
\hline & \multicolumn{3}{c}{ Patients } \\
\cline { 2 - 4 } & & \multicolumn{2}{c}{ Sex } \\
\cline { 2 - 4 } & $\boldsymbol{n}^{\mathbf{a}}$ & $\mathbf{M}$ & $\mathbf{F}$ \\
\hline CLL (Rai stage) & & & \\
0 & 8 & 5 & 3 \\
I & 8 & 8 & 2 \\
II & 8 & 6 & 1 \\
III & 9 & 8 & 5 \\
IV & 8 & 3 & 17 \\
ALL & & 21 & 1 \\
Pre-B & 38 & 3 & \\
B-PLL & 4 & & \\
\hline ALL & & & \\
\hline
\end{tabular}

$\mathrm{ALL}=$ acute lymphoblastic leukaemia; $\mathrm{B}-\mathrm{PLL}=\mathrm{B}$-cell prolymphocytic leukaemia; $\mathrm{CLL}=$ chronic lymphocytic leukaemia; pre-B $=$ precursor $\mathrm{B}$-cell. Rai stages were available for 41 out of $45 \mathrm{CLL}$ patients. ${ }^{a}$ Number of samples.

\section{PATIENTS, MATERIALS AND METHODS}

\section{Patient samples}

A total of 87 EDTA-blood samples (45 CLLs, 38 ALLs and 4 prolymphocytic leukaemias (PLLs)) were collected from Jordanian patients attending King Hussein Cancer Center and Jordan University hospital, according to protocols approved by the Institutional Review Board. Informed consent was obtained from each patient.

The CLL specimens represented all stages of the Rai staging system (Rai et al, 1975), which was available for 41 out of 45 patients, whereas all ALL and PLL specimens were of the B-cell type (Table 1).

\section{Materials and methods}

DNA was extracted from whole-blood samples using the Wizard genomic DNA purification kit (Promega, Madison, WI, USA). Polymerase chain reaction (PCR) was used to amplify genomic DNA encompassing the coding sequences and intronic borders of exon 3 of the AKT1 gene in patients' DNA. The primers used for PCR were the same as those used by Carpten et al (2007) (F: $5^{\prime}$ ACATCTGTCCTGGCACAC-3', R: 5'-GCCAGTGCTTGTTGCTTG-3').

The PCR was performed in $50 \mu \mathrm{l}$ reaction containing $200 \mathrm{ng}$ of genomic DNA, $200 \mu \mathrm{M}$ dNTPs, $1.5 \mathrm{mM} \mathrm{MgCl}_{2}, 1 \mathrm{U}$ Go Taq polymerase (Promega) and $10 \mathrm{pmol}$ of each primer (Invitrogen, Carlsbad, CA, USA). The reaction conditions were as follows: initial denaturation of $3 \mathrm{~min}$ at $95^{\circ} \mathrm{C}$, followed by 34 cycles of $30 \mathrm{~s}$ at $95^{\circ} \mathrm{C}, 30 \mathrm{~s}$ at $52^{\circ} \mathrm{C}, 1 \mathrm{~min}$ at $72^{\circ} \mathrm{C}$ and a final extension of $6 \mathrm{~min}$ at $72^{\circ} \mathrm{C}$. The PCR products were purified using the Wizard SV gel and PCR cleanup system (Promega) and then sequenced using the same PCR primers. The sequencing reactions were performed at Macrogen Inc., (Seoul, South Korea) using the Big Dye ${ }^{\mathrm{TM}}$

\section{REFERENCES}

Altomare DA, Testa JR (2005) Perturbations of the AKT signaling pathway in human cancer. Oncogene 24: 7455-7464

Barragán M, Bellosillo B, Campàs C, Colomer D, Pons G, Gil J (2002) Involvement of protein kinase $\mathrm{C}$ and phosphatidylinositol 3-kinase pathways in the survival of B-cell chronic lymphocytic leukemia cells. Blood 99: 2969-2976

Barragán $M$, de Frias $M$, Iglesias-Serret $D$, Campàs C, Castaño E, Santidrián AF, Coll-Mulet L, Cosialls AM, Domingo A, Pons G, Gil J (2006) Regulation of Akt/PKB by phosphatidylinositol 3-kinase-depen- terminator cycle sequencing kit (Applied Biosystems, Foster Ctiy, CA, USA) and the ABI 3730 XL analyzer (Applied Biosystem).

\section{RESULTS AND DISCUSSION}

The sequencing analysis for exon 3 of the human $A K T 1$ gene in 87 samples (45 CLLs, 38 pre-B-cell ALLs and 4 B-cell PLLs) revealed the absence of the point mutation $\mathrm{G}>\mathrm{A}$ at nucleotide 49 (E17K), which was first identified by Carpten et al (2007).

The genetic abnormalities seen in CLL differ from most other forms of haematological malignancies, including ALL. Although CLL is usually characterised by chromosomal deletions (Cotter and Auer, 2007), ALL and many other forms of leukaemia usually harbour chromosomal translocations in a significant number of transformed cells. Despite the extensive sequencing analysis over the last decade, no major point mutations have been identified in CLL or ALL.

Because of the oncogenic potential of the mutation E17K, and its ability to specifically induce B-cell leukaemia in mice (Carpten et $a l, 2007)$, in addition to the importance of AKT proteins in mediating survival and antiapoptotic signals in B-cell lineages of CLL and ALL, we sought to look for this mutation in B-cell lymphoid leukaemia patients. The CLL patients who were included in this study represented the stable or advanced stages of the disease; all ALL patients were of the pre-B-cell type and four patients with PLL were also included.

From our findings we conclude that the mutation E17K/AKT1 is unlikely to cause major transforming activity in B-cell-origin CLL, ALL and PLL. However, given the small size of the sample analysed, another large-scale study could increase the statistical power of our results. Also, we did not include the T-lineage cells of ALL in this study, which is something we will be working on next, as it is worthwhile to screen for the mutation in this subclass of acute leukaemia.

This report assesses the presence of E17K/AKT1 in B-cell lymphoid leukaemias, including the chronic and acute phases. Our results are supported by two recent reports, which were published while preparing this paper, by Kim et al (2008) and Zenz et al (2008), who also came to a similar conclusion regarding the significance of E17K/AKT1 in B-cell ALL and CLL, respectively. Further work is needed to investigate the possibility of analogous mutations in other AKT isoforms as well as to detect the status of this mutation in other related haematological malignancies.

\section{ACKNOWLEDGEMENTS}

This work was supported by the Molecular Biology Research Laboratory (Faculty of Medicine, University of Jordan). We are grateful to Dr Nazzal AL-Bsoul and Dr Mahmoud Ayesh for their assistance. We thank the staff of the Hematology Departments of Jordan University Hospital and King Hussein Cancer Center. dent and -independent pathways in B-cell chronic lymphocytic leukemia cells: role of protein kinase C $\beta$. J Leukoc Biol 80: $1473-1479$

Bellacosa A, Kumar CC, Di Cristofano A, Testa JR (2005) Activation of AKT kinases in cancer: implications for therapeutic targeting. Adv Cancer Res 94: $29-86$

Carpten JD, Faber AL, Horn C, Donoho GP, Briggs SL, Robbins CM, Hostetter G, Boguslawski S, Moses TY, Savage S, Uhlik M, Lin A, Du J, Qian YW, Zeckner DJ, Tucker-Kellogg G, Touchman J, Patel K, Mousses 
S, Bittner M, Schevitz R, Lai MH, Blanchard KL, Thomas JE (2007) A transforming mutation in the pleckstrin homology domain of AKT1 in cancer. Nature 448: $439-444$

Cotter FE, Auer RL (2007) Genetic alteration associated with chronic lymphocytic leukemia. Cytogenet Genome Res 118: 310-319

Cuní S, Pérez-Aciego P, Pérez-Chacón G, Vargas JA, Sánchez A, MartínSaavedra FM, Ballester S, García-Marco J, Jordá J, Durántez A (2004) A sustained activation of PI3K/NF-kappaB pathway is critical for the survival of chronic lymphocytic leukemia B cells. Leukemia 18: $1391-1400$

Elstrom RL, Bauer DE, Buzzai M, Karnauskas R, Harris MH, Plas DR, Zhuang H, Cinalli RM, Alavi A, Rudin CM, Thompson CB (2004) Akt stimulates aerobic glycolysis in cancer. Cancer Res 64: 3892-3899

Hanada M, Feng J, Hemmings B (2004) Structure, regulation and function of PKB/AKT - a major therapeutic target. Biochem Biophys Acta 1697: $3-16$

Inamdar KV, Bueso-Ramos CE (2007) Pathology of chronic lymphocytic leukemia: an update. Ann Diagn Pathol 11: 363-389

Kim MS, Jeong EG, Yoo NJ, Lee SH (2008) Mutational analysis of oncogenic AKT E17K mutation in common solid cancers and acute leukaemias. $\mathrm{Br} J$ Cancer 98: 1533 - 1535

Longo PG, Laurenti L, Gobessi S, Petlickovski A, Pelosi M, Chiusolo P, Sica S, Leone G, Efremov DG (2007) The Akt signaling pathway determines the different proliferative capacity of chronic lymphocytic leukemia B-cells from patients with progressive and stable disease. Leukemia 21: $110-120$

Longo PG, Laurenti L, Gobessi S, Sica S, Leone G, Efremov DG (2008) The Akt/Mcl-1 pathway plays a prominent role in mediating antiapoptotic signals downstream of the B-cell receptor in chronic lymphocytic leukemia B cells. Blood 111: 846 -855

Malanga D, Scrima M, De Marco C, Fabiani F, De Rosa N, de Gisi S, Malara N, Savino R, Rocco G, Chiappetta G, Franco R, Tirino V, Pirozzi G Viglietto G (2008) Activating E17K mutation in the gene encoding the protein kinase AKT in a subset of squamous cell carcinoma of the lung. Cell Cycle 7: 665-669

Manning BD, Cantley LC (2007) AKT/PKB signaling: navigating downstream. Cell 129: 1261 - 1274

Nicholson KM, Anderson NG (2002) The protein kinase B/Akt signaling pathway in human malignancy. Cell Signal 14: 381-395
Petlickovski A, Laurenti L, Li X, Marietti S, Chiusolo P, Sica S, Leone G, Efremov DG (2005) Sustained signaling through the B-cell receptor induces Mcl-1 and promotes survival of chronic lymphocytic leukemia B cells. Blood 105: 4820-4827

Plas DR, Thompson CB (2005) Akt-dependent transformation: there is more to growth than just surviving. Oncogene 24: 7435-7442

Rai KR, Sawitsky A, Cronkite EP, Chanana AD, Levy RN, Pasternack BS (1975) Clinical staging of chronic lymphocytic leukemia. Blood 46: $219-234$

Robertson GP (2005) Functional and therapeutic significance of Akt deregulation in malignant melanoma. Cancer Metastasis Rev 24: $273-285$

Sarkar S, Svoboda M, de Beaumont R, Freedman AS (2002) The role of Akt and RAFTK in betal integrin mediated survival of precursor B-acute lymphoblastic leukemia cells. Leuk Lymphoma 43: 1663-1671

Schüller U, Ruiter M, Herms J, Kretzschmar HA, Grasbon-Frodl E (2008) Absence of mutations in the AKT1 oncogene in glioblastomas and medulloblastomas. Acta Neuropathol 115: $367-368$

Soung YH, Lee JW, Nam SW, Lee JY, Yoo NJ, Lee SH (2006) Mutational analysis of AKT1, AKT2 and AKT3 genes in common human carcinomas. Oncology 70: 285-289

Staal SP, Hartley JW, Rowe W (1977) Isolation of transforming murine leukemia viruses from mice with a high incidence of spontaneous lymphoma. Proc Natl Acad Sci USA 74: 3065-3067

Staal SP, Hartley JW (1988) Thymic lymphoma induction by the AKT8 murine retrovirus. J Exp Med 167: 1259-1264

Testa JR, Bellacosa A (2001) AKT plays a central role in tumorigenesis. Proc Natl Acad Sci USA 98: 10983 - 10985

Tibes R, Kornblau SM, Qiu Y, Mousses SM, Robbins C, Moses T, Carpten JD (2008) PI3K/AKT pathway activation in acute myeloid leukaemias is not associated with AKT1 pleckstrin homology domain mutation. $\mathrm{Br} \mathrm{J}$ Haematol 140: $344-347$

Wang L, Fortney JE, Gibson LF (2004) Stromal cell protection of B-lineage acute lymphoblastic leukemic cells during chemotherapy requires active Akt. Leuk Res 28: $733-742$

Zenz T, Döhner K, Denzel T, Döhner H, Stilgenbauer S, Bullinger L (2008) Chronic lymphocytic leukaemia and acute myeloid leukaemia are not associated with AKT1 pleckstrin homology domain (E17K) mutations. $\mathrm{Br}$ J Haematol 141: 742 - 743 